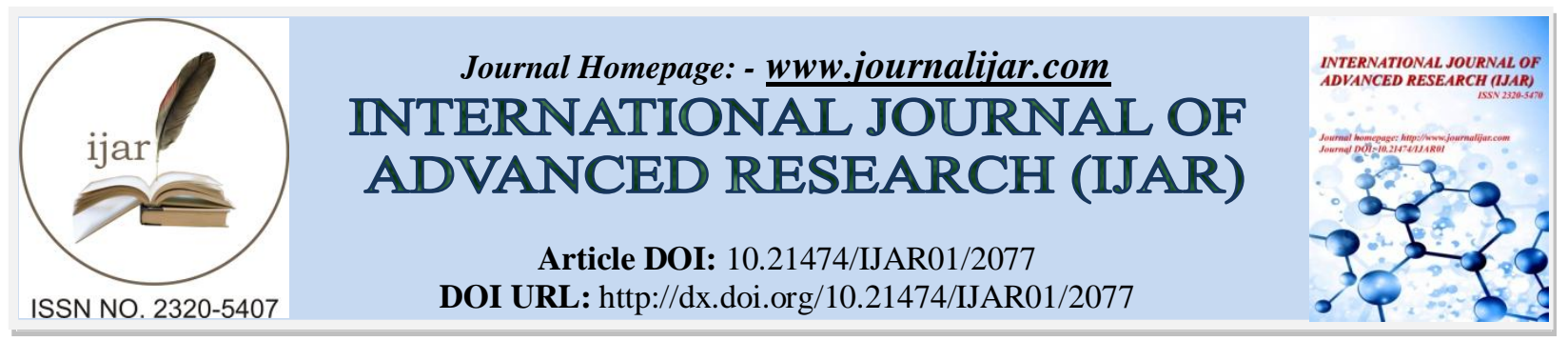

RESEARCH ARTICLE

\title{
ENVIRONMENTAL TOXICITY EFFECT OF ENDOSULFAN ON PROTEIN LEVELS IN BRAIN AND MUSCLE OF FRESHWATER FISH, Channa Striatus (BLOCH).
}

\author{
Prakash Sahaya Leon $\mathrm{J}^{* 1}$, Mariappan $\mathrm{M}^{\mathbf{2}}$, Manivelu $\mathrm{D}^{\mathbf{1}}$, Balakrishnan $\mathrm{K}^{\mathbf{3}}$ and Venkatesan $\mathrm{J}^{\mathbf{1}}$ \\ 1. P.G and Research Department of Zoology, Government Arts College for Men, Krishnagiri. \\ 2. Department of Zoology, Government Arts College, Gudiyatham. \\ 3. Department of Zoology, Government Arts College (Autonomous), Karur.
}

\section{Manuscript Info}

Manuscript History

Received: 24 September 2016

Final Accepted: 26 October 2016

Published: November 2016

Key words:-

Channa striatus, endosulfan, protein.

\section{Abstract}

Pesticides are used all over the world to control the insects, pests of food crops, and livestock. Due to their injudicious and indiscriminate usage, water bodies are continuously polluted. Pesticides, ultimately finds their way into aquatic habitats such as rivers, lakes and ponds, and have been found to be toxic to organisms. Most of the pesticides enter into the food chain are cause physiological damage for the aquatic organisms also develop various metabolic abnormalities. Endosulfan, an organochlorine pesticide, is recognized as a persistently toxic substance and considered as a potential organic pollutant. Endosulfans had been reached alarming level in water bodies and soil sediments and were also detected in animal samples. Endosulfan is extremely toxic to fish and it cause massive effect. The present study is to assess the protein content in brain and muscle of the fresh water fish Channa striatus exposed to sublethal concentration of endosulfan $1 / 10^{\text {th }}$ (high), $1 / 15^{\text {th }}$ (medium), $1 / 20^{\text {th }}$ (low) of the 96 hour $\mathrm{LC}_{50}$ value for the period of 7,14 and 21 days. The fish exposed to endosulfan showed, gradual decreases in protein level for 7, 14 and 21 days in brain and muscle tissue. The depletion of protein content in brain and muscle tissue of fresh water fish, Channa striatus was due to the utilization of protein to counteract the toxicant stress caused by pesticide.

Copy Right, IJAR, 2016,. All rights reserved.

\section{Introduction:-}

Pesticides have been widely used all over the world to control insects, pests and disease vectors and they are one of the most potentially harmful chemicals introduced into the environment, though they have contributed considerably to human welfare, their adverse effects on non-target organisms are significant. A large number of pesticides, which are drained in water bodies, develop various metabolic abnormalities. They accumulate in fish and affect human health too via biological magnification.

One of the most common environmental pollutants entering the aquatic system both in industrial effluents and runoff from agricultural chemicals is organochlorine pesticide. This organochlorine pesticide has gained significance as a potential environmental pollutant due to its wide spread use in the control of agricultural insect pests (Merhrk et al., 1971). It is highly persistent and non-biodegradable. The organochlorine insecticide endosulfan 
is a highly toxic; it acts primarily on the nervous system. Fish and other aquatic organisms may show signs of its effects, although they are not the target of this pesticide (Fanta et al., 2003). Toxicity of endosulfan to non-target animals have been thoroughly reviewed by Naqvi and Vaishanavi, 1993.

Aquatic animals have been known to accumulate considerably greater quantities of endosulfan (Ponmani and Dhanakkodi, 1996; Ponmani et al., 1998 ). Endosulfan has been found to be generally more toxic to fish than invertebrates (EPA, 1980). In rainbow trout (Oncorhynchus mykiss) endosulfan has caused a wide range of effects including: hyperactivity, convulsions, paralysis, erratic behaviour, and eventually death through water borne and feed borne exposures (Broomhall, 2002; Naqvi and Vaishnavi, 1993). Several physiological functions are disturbed by this organochlorine insecticide during short-term intoxication: oxygen uptake, blood lactic acid and lipid metabolism (Bakthavathsalam and Reddy, 1981; Gluth and Hanke, 1985).

Endosulfan toxicity produces changes in concentration of protein, glycogen and lipid in Channa punctatus (Murty and Devi, 1982) Barilius bendelisis (Deoray and Desai, 1997) and Cyprinus carpio (Dhasararathan et al., 2000). The physiological and biochemical alterations observed in an animal under any physiological stress can be correlated with the structural and functional changes of cellular proteins. Proteins occupy a unique position in the metabolism of cell because of the proteinaceous nature of all the enzymes which mediate at various metabolic pathways (Lehninger, 2008; Harper, 2006). The protein content in the tissues of animals plays a role in the metabolism of animals (Palanivelu et al 2005). Morthy and Priyamvada (1982) stated that the protein content of the cell may be considered as an important tool for evaluation of physiological standards.

The present investigation was to assess the protein contents in brain and muscle of Channa striatus exposed to three different sublethal concentration of endosulfan.

\section{Materials and methods:-}

The fish Channa striatus having mean weight of 25-30 gm and length of $22-24 \mathrm{~cm}$ were collected from PSP fish farm, at Puthur and acclimatized in to laboratory conditions. They were given the treatment of $0.1 \%$ KMNO4 solution and then kept in plastic pools for acclimatization for a period of two weeks. They were fed on rice bran and oil cake daily. The endosulfan was used in this study and stock solutions were prepared. Endosulfan LC50 was found out for $96 \mathrm{~h}(6.82 \mu \mathrm{g} / \mathrm{L})$ (Sprague, 1971) and 1/20th, 1/15th and 1/0th of the LC50 values were 0.34 , 0.45 and $0.68 \mu \mathrm{g} / \mathrm{L}$ respectively taken as sublethal concentrations for this study. Forty fish were selected and divided into 4 groups of 10 each. The first group was maintained in free from endosulfan and served as the control. The other 3 groups were exposed to sub lethal concentration of endosulfan 10 litre capacity aquaria. The 2nd, 3rd and 4th groups were exposed to endosulfan for 7, 14 and 21 days respectively. At the end of each exposure period, the fish were sacrificed and the required tissues were collected for protein estimation. Protein contents in the tissues were estimated by the method of Lowry et al. (1951).

The data so obtained were analyzed by applying analysis of variance DMRT one way ANOVA to test the level of significance (Duncan, 1957).

Chemical:-

The physicochemical properties of used chemical were tabulated in Table 1.

\begin{tabular}{|l|c|}
\hline \multicolumn{1}{|c|}{ PROPERTIES } & ENDOSULFAN \\
\hline Chemical formula & $\mathrm{C}_{9} \mathrm{~N}_{6} \mathrm{Cl}_{6} \mathrm{O}_{3} \mathrm{~S}^{\mathrm{c}}$ \\
\hline Molecular weight & 406.93 \\
\hline Physical state at room temperature & Crystalline solid \\
\hline Colour & Green to brown \\
\hline Vapour pressure at $25^{\circ} \mathrm{C}$ & $1 \times 10^{-6} \mathrm{~mm} \mathrm{Hg}$ \\
\hline Flammability & Non-flammable \\
\hline Boiling point & $106^{\circ} \mathrm{C}$ \\
\hline Density at $20 / 4^{\circ} \mathrm{C}$ & $1.745 \mathrm{~g} \mathrm{~mL}^{-1}$ \\
\hline
\end{tabular}




\section{Results:-}

The protein levels in brain and muscle of Channa striatus exposed to low, medium and high sublethal concentration of endosulfan showed significant decrease when compared to control fish. The decrease in brain and muscle of Channa striatus protein levels were more pronounced at 21 days of exposure periods (Table 1 and 2).

Table 1:- Protein (mg/g) in brain of Channa striatus exposed to sublethal concentrations of endosulfan

\begin{tabular}{|c|c|c|c|}
\hline & 7 Days & 14 Days & 21 Days $^{\mathrm{a}}$ \\
\hline Control & $83.04 \pm 6.32^{\mathrm{b}}$ & $83.12 \pm 6.32^{\mathrm{d}}$ & $85.01 \pm 6.47^{\mathrm{d}}$ \\
\hline Low concentration & $78.11 \pm 5.94^{\mathrm{b}}$ & $74.10 \pm 5.64^{\mathrm{c}}$ & $69.03 \pm 5.25^{\mathrm{c}}$ \\
\hline Medium concentration & $70.24 \pm 5.33^{\mathrm{a}}$ & $61.05 \pm 4.65^{\mathrm{b}}$ & $53.01 \pm 4.03^{\mathrm{b}}$ \\
\hline High Concentration & $64.15 \pm 4.87^{\mathrm{a}}$ & $48.00 \pm 3.65^{\mathrm{a}}$ & $41.01 \pm 3.12^{\mathrm{a}}$ \\
\hline
\end{tabular}

All the values mean \pm SD of six observations Values which are not sharing common superscript differ significantly at $5 \%(\mathrm{p}<0.05)$ Duncan multiple range test $(\mathrm{DMRT})$

Table 2. Protein (mg/g) in muscle of Channa striatus exposed to sublethal concentrations of endosulfan

\begin{tabular}{|l|c|c|c|}
\hline & 7 Days & 14 Days & 21 \\
\hline Control & $75.01 \pm 5.71^{\mathrm{b}}$ & $78.02 \pm 5.94^{\mathrm{d}}$ & $76.04 \pm 5.78^{\mathrm{d}}$ \\
\hline Low concentration & $71.33 \pm 5.41^{\mathrm{b}}$ & $69.07 \pm 5.25^{\mathrm{c}}$ & $65.02 \pm 4.95^{\mathrm{c}}$ \\
\hline Medium concentration & $64.06 \pm 4.87^{\mathrm{a}}$ & $61.09 \pm 4.64^{\mathrm{b}}$ & $52.00 \pm 3.96^{\mathrm{b}}$ \\
\hline High Concentration & $58.01 \pm 4.41^{\mathrm{a}}$ & $49.00 \pm 3.73^{\mathrm{a}}$ & $44.07 \pm 3.35^{\mathrm{a}}$ \\
\hline
\end{tabular}

All the values mean \pm SD of six observations Values which are not sharing common superscript differ significantly at $5 \%(\mathrm{p}<0.05)$ Duncan multiple range test (DMRT)

\section{Discussion:-}

Endosulfan, an organochlorine pesticide, is used to control insects and mites infesting crops including vegetables, fruits, tea, coffee, cotton, rice and grains (Thangavel et al., 2010). Excessive application of pesticides near agriculture field leads to found the surrounding aquatic medium through wind action and agriculture runoff. The non-target organisms like fish, crab, prawn and other aquatic animals are severely affected by the action of pesticides and reduction of the nutrients like carbohydrate, protein and lipids in the organisms. Protein is the most primary biochemical ingredient present in large quantities in the body of fish. In the present investigation brain and muscle of protein levels decreased at all periods of exposure when Channa striatus was exposed to sublethal concentrations of endosulfan.

The depletion of proteins under the stress of chlorpyrifos toxicity observed in different tissues of Catla catla, Labeo rohita and Cirrhinus mrigala indicates the proteolysis, suggesting that the proteins were utilized to meet the excess energy demands imposed by the toxic stress. The protein content declined gradually in gill, liver and muscle tissues of $O$. mossambicus when exposed to deltamethrin and it was reported that it may be due to the utilization of protein controls to counteract the toxicant stress caused by pesticide (Rao and Rao, 1979; Rath and Mishra, 1980). The sublethal concentrations of endosulfan caused a significant reduction in the liver protein content of Channa striatus at all exposure periods. The liver gets affected considerably when there is a disturbance in protein metabolism. The accumulation of toxic substance in liver may alter its function (Premdas and Anderson, 1963). The different concentrations of malathion, thiodon and ekalux significantly reduced the total protein in liver of $O$. mossambicus (Palanichamy et al., 1986). Similar observations were noted when the fish were exposed to pollutants (Lone and Javaid, 1976; Shakoori et al., 1976; Rath and Mishra, 1980; Ramalingam and Ramalingam, 1982). The sublethal concentrations of endosulfan caused a significant reduction in the kidney protein content of Channa striatus at all exposure periods. Rao et al., (1980) and Devi (1981) reported that the kidney was the site of degradation and detoxification of toxic substances.

Reduction in protein levels was observed in the gills of Channa pitnctatus exposed to monocrotophos (Agrahari et al, 2006) and alimentary tract of Oreochromis niloticus exposed to diazinon (Durmaz et al., 2006). Begam and Vijayaraghavan (1996) observed protein depletion in the fish indicates the physiological strategy in order to meet the energy demand and to adapt itself to the changed metabolic system which may lead to the stimulation of 
degradative processes like proteolysis and utilization of degraded products for increased energy metabolism. In general, organophosphorus and organochlorine pesticides are known to depress blood protein in fishes (Grant and Mehrle 1973; Mukhopadhyay and Dehadrai 1980). Depletion of tissue protein in fishes exposed to various pesticides toxicant has been reported by many workers (Eisler and Edmunds 1996; Mehrle et al 1971 and Kabar et al 1978; Mukhopadhy and Dehadrai 1980). Further it has been reported that acute or chronic treatment of pesticide cause biochemical alterations in the organs involved in detoxification mechanisms (Dishit et al 1975; Sastry and Sharma 1979; Avan Maruthi et al 2000; Shobana Rani et al 2000 and Prabhakar et al 2002).

Bhaskaran (1980) and Manoharan and Subbiah (1982) reported that depletion in protein level was due to diversification of energy to meet the impending energy demand when the animals were under toxic stress. Many investigators recorded such a reduction in protein content in different tissues when the animals were exposed to different pollutants (Shah and Dubale, 1983; Ram and Sathyanesan, 1986; Palanichamy et al., 1986; Malla Reddy and Bashamohideen, 1987, 1988; Jeyachandran and Chockalingam, 1987; Karuppasamy, 1990; Rao, 1989). It is evident that proteins are degraded to meet the energy requirements during endosulfan exposure.

A reduction in the protein content in the present investigation in Channa striatus suggests that the tissue protein undergoes proteolysis which results in an increase in the production of free amino acids. These amino acids are utilized for energy production during stressful situation in the intoxicated fishes. The results of the present findings showed a significant decrease in protein levels in brain and muscle of Channa striatus exposed to sublethal concentrations of endosulfan at 7,14 and 21 days. It can be concluded that Channa striatus exposed to endosulfan at sublethal concentrations causes energy crisis and alter protein metabolism.

\section{Acknowledgement:-}

The authors wish to thank the authorities of Annamalai University for providing the facilities to carry out the work.

\section{References:-}

1. Avsan Maruthi, Y. and M.V. Subha Rao, 2000. Effects of distillery effluents on biochemical parameters of fish Channa punctatus (Bloch). J. Environ. Poll., 12: 111 - 112.

2. Bakthavathsalam, R. and Y.S. Reddy, 1981. Lipid kinetics in relation to the toxicity of three pesticides in the climbing perch, Anabas testudineus. Proc. Indian. Natn. Sci. Acad., 47(B): 670-676.

3. Bhaskaran, R., 1980. Biological studies on a chosen thermo conformer Channa striatus. Ph.D. Thesis, Madurai Kamaraj University.

4. Broomhall, S., 2002. The effects of endosulfan and variable water temperature on survivorship and subsequent vulnerability to predation in Litoria citropa tadpoles. Aqua. Toxicol., 61: 243-250.

5. Cruz-Laeierda Erlinda, R., Yukio Maeno, April Joy, T. Pineda and V.E. Matey, 2004. Mass mortality of hatchery - reared milkfish (Chanos chanos) and mangrove red snapper (Lutjanus argentimaculatus) caused by Amyloodinium ocellatum (Dinoflagellida) Aquaculture, 236: 85-94.

6. Deoray, B. M. and A.E. Desai, 1997. Thidon intoxication effects on liver content of the cyprinid

7. fish, Barilius bendelisis. Geobios., 24: 146-150.

8. Devi, A.P., 1981. Studies on the toxicity of endosulfan to some freshwater fish with special reference to certain physiological changes induced in Channa punctatus (Bloch.). Ph.D. Thesis, Nagarjuna University.

9. Dhasararathan, P., R. Palaniappan and A.J.A. Ranjit Singh, 2000. Effect of endosulfan and butachlor on the digestive enzyme and proximate compostion of the fish, Cyprinus carpio. Indian J. Environ. Ecoplan., 3: 611614.

10. Dikshit, T.S.S., J.F. Behari, F.K. Datta and A.K. Mathur, 1975. Effects of diazinon in male rats

11. "Histopathological and biochemical studies". Environ. Physiol. Biochem., 51 : 293 - 299.

12. Duncan, D.B., 1957. Multiple range tests for correlated and heteroscedastic means. Biometrics, 13: 359-364.

13. Eisler, R. and P.H. Edmunds, 1966. Effects of endrin on blood and tissue chemistry of a marine

14. fish. Trans. Amer. Fish. Soc., 95: 153 - 159.

15. EPA, 1980. Ambient water quality criteria for endosulfan. Env. Res. Sab. Gulf. Breeze, FLA

16. Rept No. 4405-80-046, 108.

17. European Food Safety Authority (EFSA), 2005. Opinion of the scientific panel on contaminants in the food chain on a request from the commission related to endosulfan as undesirable substance in animal feed. EFSA J., 234: $1-29$. 
18. Fanta, E., F. Sant'Anna Rios, S. Romao, A. Casagrande Vianna and S. Freiberger, 2003. Histopathology of the fish Corydoras paleatus contaminated with sublethal levels of organophosphorus in water and food. Ecotoxicol. Environ. Saf., 54: 119-130.

19. Gluth, G. and W. Hanke, 1985. A comparison of physiological changes in carp, Cyprinus carpio, induced by several pollutants at sublethal concentrations. The dependency on exposure time. Ecotoxicol. Environ. Safety, 9:179-188.

20. Harper's Illustrated Biochemistry ( $27^{\text {th }}$ Edn.) Robert K. Murray, Daryl K. Granner and W. Victor Rodwell: Lange Medical publications, Asia, Singapore, 74-75 (2006).

21. Jeyachandran, K.P.S. and S. Chockalingam, 1987. Effects of tannery effluent on respiratory parameters and biochemical constituents in an air-breathing fish Channa punctatus. Comp. Physiol. Ecol., 12: 197-200.

22. Kabeer Ahammad Sahib, I., K.R.S. Sambasiva Rao and K.V. Ramana Rao, 1978. Effect of malathion on free amino acids to the protein, glycogen and some enzymes of Pelypod Lamellidens marginalis (Lamarck). Proc. Ind. Acad. Sci., 87(12): 377 - 387.

23. Karuppasamy, R., 1990. Toxicity impact of sugar mill effluent on freshwater fish Channa punctatus (Bloch). M.Phil. Thesis, Annamalai University.

24. Lehninger, 2008. Principles of Biochemistry 5th Edn. Michael M.Cox and David L. Nelson. New York. 570572.

25. Lone, K.P. and M.Y. Javaid, 1976. Effect of sublethal dose of DDT and dieldrin in the blood of Channa punctatus. Pak. J. Zool., 8: 143.

26. Lowry, D.H., N.J. Rosebrough, A.L. Farr and R.J. Randall, 1951. Protein measurement with the folin phenol reagent. J. Biol. Chem., 193: 265-275.

27. Malla Reddy, P. and M.D. Bashamohindeen, 1987. Biochemical changes in kidney and intestine of freshwater fish Cyprinus carpio exposed to malathion. Environ. Ecol., 5: 378-380.

28. Manoharan, T. and Subbiah, 1982. Toxic and sublethal effect of endosulfan on Barbus stigma. Proc. Ind. Acad. Anim., Sci., 91: 523-532.

29. Merhrk, P.M., D.L. Stalling and R.A. Bloomfiled, 1971. Serum amino acid in rainbow trout Salmo gairdneri as affected by DDT and aldrin. Com. Biochem. Physiol., 38(B): 373 - 377.

30. Merhrk, P.M., D.L. Stalling and R.A. Bloomfiled, 1971. Serum amino acid in rainbow trout Salmo gairdneri as affected by DDT and aldrin. Com. Biochem. Physiol., 38(B): 373 - 377.

31. Morthy, A.S. and D. Priyamvada, 1982. The effects of endosulfan and its isomers on tissue protein glycogen and lipids in the fish Channa punctatus. J. Pestic. Biochem. Physicl., $17: 280-286$.

32. Murty, A. S. and A.P. Devi, 1982. The effect of endosulfan and its isomers on tissue protein, glycogen and lipid in the fish, Channa punctatus. Pest. Biochem. Physiol., 17: 280-286.

33. Naqvi, S.M. and C. Vaishnavi, 1993. Bioaccumulative potential and toxicity of endosulfan insecticide to nontarget animals. Comp. Biochem. Physiol., 105: 347- 361.

34. Palanichamy, S., P. Baskaran and M.P. Balasubramanian, 1986. Sublethal effects of malathion, thiodon and ekalux on protein, carbohydrate and lipid contents of muscle and liker of Oreochromis mossambicus. Proc. Sym. Pest. Resid. Environ. Poll., 97-102.

35. Palanivelu, V., K. Vijayavel, S. Balasubramanian and M.P. Balasubramanian, 2005. Influence of insecticidal derivative (Cartap hydrochloride) from the marine polycheate on certain enzyme systems of the fresh water fish Oreochromis mossambicus. J. Environ. Biol., 26:191-195.

36. Ponmani, R. and B. Dhanakkodi, 1996. Bioaccmulation and elimination of endosulfan in Cyprinus carpio. J. Environ. Poll., 3: 191-194.

37. Ponmani, R., B. Dhanakkodi, R.S. Mohanraj and K. Thangavel, 1998. Sublethal effect of

38. endosulfan on food utilization of Cyprinus carpio. Indian J. Environ., 1: 49-51.

39. Prabhakara Rao and P.V. Prasad Rao, 2002. Pollution potential of sago industry. A case study. $J$.

40. Ecotoxicol. Environ. Monit., 12 (1) : 53 - 56.

41. Premdas, F.H. and J.M. Anderson, 1963. The uptake and detoxification of 14C labeled DDT in Atlantic salmon Salmo Salar. J. Fish. Res. Bd. Canada, 30: 837.

42. Ram, R.N. and A.G. Sathyanesan, 1986. Effect of two mercuric compounds on the protein, RNA and DNA contents in the brain, liver and ovary of the fish Channa punctatus. Environ. Ecol., 4: 24-29.

43. Ramalingam, K. and K. Ramalingam, 1982. Effects of sublethal levels of DDT malathion and mercury on tissue proteins of Sarotherodon mossambicus (Peters). Proc. Indian. Acad. Sci., 91: 501-505.

44. Rao, D.M., A.P. Devi and A.S. Murthy, 1980. Relative toxicity of endosulfan, its isomers and

45. formulated products to the freshwater fish Labeo rohita. J. Toxicol. Environ. Hlth., 6: 323. 
46. Rao, K.S.P. and K.V.R. Rao, 1979. Effect of sublethal concentration of methyl parathion on selected oxidative enzymes and organic constituents in the tissues of freshwater fish, Tilapia mossambica. Curr. Sci., 48: 526-528.

47. Rao, P.S. and V.S. Durve, 1989. Fish and fisheries of Lake Jaisamand, Rajasthan: Indian Journal of Fisheries, 36: 47-52.

48. Rath, S. and B.N. Mishra, 1980. Changes in nucleic acid and protein content of Tilapia mossambica exposed to dicholorvos (DDVP). Indian J. Fish, 27: 76-81.

49. Sastry, K.V. and S.K. Sharma, 1979. Toxic effects of endrin on liver and kidney of a teleost fish.

50. Proc. Sym. Environ. Biol., 339 - 342.

51. Shah, P.H. and M.S. Dubale, 1983. Biochemical changes induced by malathion in the body organs of Channa punctatus. J. Anim. Morphol., 30: 107-118.

52. Shakoori, A.R., A.Z. Saleem and S.A. Muhamed, 1976. Effect of malathion, dieldrin and endrin on blood serum proteins and free amino acids pool in Channa punctatus (Bloch). Pak. J. Zool., 8: 124-134. 337

53. Shobana Rani, D., R. Sudhar san, T.N. Reddy, P.V. Reddy and T.N. Raju, 2001. Effects of arsenic on certain aspects of protein metabolism in fresh water teleost Tilapia mossambica (Peters). J. Environ. Biol., 22(2) : 101 $-104$.

54. Sprague, J.B., 1971. Measurement of pollutant toxicity to fish. III. Sublethal effects and Safe concentrations. Water Res., 5:245-266.

55. Thangavel, P., K. Sumathiral, S. Maheswari, S. Rita and M. Ramaswamy,2010. Hormone profile of an edible, freshwater teleost, Sarotherodon mossambicus (Peters) under endosulfan toxicity. Pest. Biochem. Physiol., 97: 229-234. 